\title{
An Analysis of Land Use Succession and Property Value in Ile-Ife, Nigeria
}

\section{| Olusola Oladapo MAKINDE ${ }^{1}$ | Olubukunmi Temitope MAKINDE ${ }^{2}$ |}

\author{
${ }^{1}$ Department of Architecture, \\ Ladoke Akintola University of \\ Technology, Ogbomosho, Oyo \\ State, Nigeria \\ ${ }^{2}$ Department of Estate \\ Management, Obafemi \\ Awolowo University, Ile-Ife, \\ Nigeria \\ ${ }^{1}$ makindeolusola2012@yahoo.com \\ ²bukunmakinde2019@gmail.com
}

\begin{abstract}
Land use succession systems have played a crucial role in cities transformation, evading and mitigating the adverse impacts on property value and unplanned development. However, such developments were not aimed at ensuring orderly spatial development which is consistent with land use and sustainable development. This study determined the trends in properties values between the year 2002 and 2016 and examined the relationship between rental values and types of Land Use Succession (LUS) in lle-Ife, Nigeria. This was to provide information that could enhance property investment decision.

Both primary and secondary data were used for the study. Primary data were obtained through the use of the questionnaire. This was administered to landlords, Estate Surveyors and Valuers and on the official of Ife Central Town Planning and Land Services Department. Data were collected from the respondents on the three major roads where LUS was prevalent. Four hundred and fifty buildings were identified out of which $50 \%$ were selected. Data collected were analyzed using descriptive and inferential statistics such as trend analysis and Analysis of variance (ANOVA).

The result showed that residential properties increased by $42.2 \%$ while commercial property increased by $57.8 \%$ between the year 2002 and 2016. The result also showed a significant statistical relationship between properties values and types of LUS with corresponding P-values of $0.000,0.000$ and 0.019 for residentialcommercial, residential cum commercial and residential-religion types of LUS respectively. The study concluded that an increase in rental value as a result of LUS is capable of enhancing property investment decision.

KEYWORDS

Land use; Succession; urban planning; sustainability; Property Value
\end{abstract}

\section{INTRODUCTION}

The effect of land-use succession on property value over the years in Ile-Ife city has not been investigated. Therefore, an understanding of the nature of urban land use succession in the town especially along the residential and commercial centres in the city is vital for property investment decision and sustainable development. Hence, it becomes very important to assess land-use succession to predict future changes in property value in the study area. One holistic technique that can be used to analyse this interaction, is to study the land-use succession in the urban area of Ile-Ife in an attempt to identify the different types of land use succession that had occurred. If such land succession types can be determined, and by deduction, their causes identified, this will help in predicting the future uses of land and building in the city in a similar set of circumstances. 
The study of land use succession and the effects on property value are essential to establish their influences on the urban area of Ile-Ife city changing land use structure. The result of this study can be used to project rental values in the surroundings and be able to determine the types of land use succession that will occur as the business districts expand. Furthermore, the understanding of the future of the city can help building professions to determine the property value of an area in the future and planning process and sustainable development. City expansion is an inevitable outcome of development. The result of this study will increase the understanding of how land-use successions had reached their current state and the changes that are likely to occur over time in the study area. The study of land use succession will account for the changes from one type of land use to another over a given period and within a given area (Kabanze, 2003).

There is a need to investigate the potential of using qualitative and quantitative research method to determine the effect of land-use succession on property value in Ile-Ife. This study will help developers, investors, lenders, appraisers, and asset managers, land use regulators and elected government officials to improve their decision-making, strategies, and understanding of the effects of land-use succession factors on property values. Information on land use succession and potential for their most favourable use is necessary for the planning, selection and execution of land use schemes to meet the mounting demands for essential human wants needs and welfare. This study will provide an index for future land use, for the government at all level and private developers. This study will also assist in examining the dynamics of land use succession consequential on changing demands of increasing population. The result of this study will educate the general public on the implications of land-use succession. In light of the foregoing, existing work on the upshot of land-use succession on property value in the urban area of the city are scanty. However, the experience of Ile-Ife as regards land-use succession becomes imperative and also an important aspect of the investigation. Hence this study seeks to investigate the effects of land-use succession on property value in Ile-Ife, Nigeria.

\section{The Study Area}

Ile- Ife is an ancient city of Yoruba land otherwise known as the source of Yoruba tribe and the first settlement in southwestern Nigeria. The city is located in the current day Osun State, South-western Nigeria. It is made up of four Local Government Areas: Ife Central, Ife East Ife North and Ife South. It has a population of about 2.5million. Ile-Ife people are of the Yoruba ethnic group and among one of the largest ethnolinguistic groupings in Africa. It is located between latitudes $7^{\circ} 28^{\prime} \mathrm{N}$ and $7^{\circ} 45^{\prime} \mathrm{N}$ and longitudes $4^{\circ} 30^{\prime} \mathrm{E}$ and $4^{\circ} 34^{\prime} \mathrm{E}$.

Figure 1 and 2 below illustrates the Map Ife Central LGA and Ile-Ife Center, and Political Map of the study area.

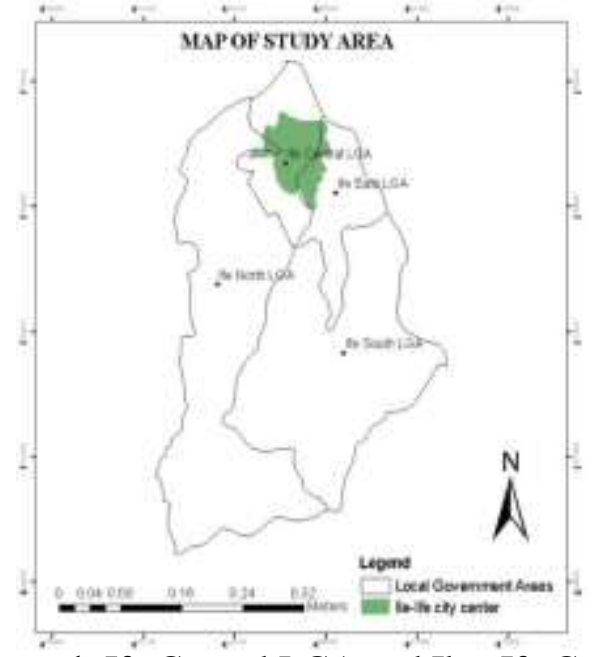

Figure 1. Ife Central LGA and Ile -Ife Center $-134-$ 


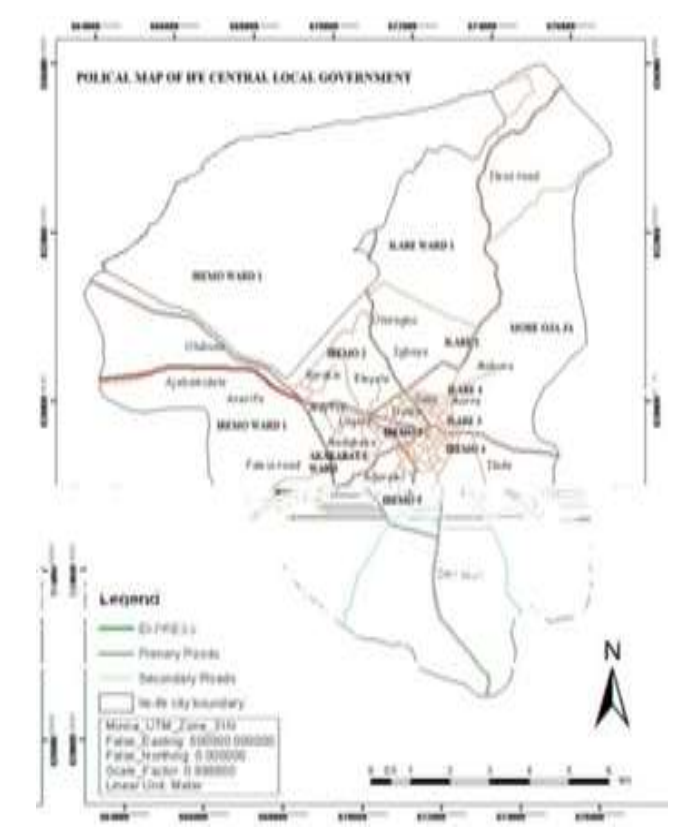

Figure 2. Political Map of the study area

\section{THEORETICAL REVIEW}

\section{Evaluation of Empirical Studies on Land Use Succession and Property Value.}

The challenges faced by properties investors are very high, especially along the major roads. This is a serious concern to investors, government and the building professionals. However, frequent change in the use of land and buildings which put pressure on the existing residential stock often makes many to lose their possessions and affected property values. Few studies had however been conducted in the literature to show the relationship between land use succession and property value. The work of Hassan (2015) examined land-use succession and real estate transaction in Ilorin metropolis. The study which identified and examined land-use succession types and factors influencing land-use succession and also investigated the implications of land-use succession did not consider the relationship between rental value and types of land use succession, which is the focus of this study. Olaore (1998) examined values of land and rent of shelter in urban areas Kaduna, were examined. The study established the land value trend in Kaduna and the influence of infrastructural facilities was also examined. The study, however, did not examine the relationship between property value and type of land use succession. Farinmade (2007) study investigated the level of conversion of land use and their implications in Nigerian cities with a focus on Surulere Local Government, Lagos. The study did not determine the trend in the rental value of the property.

Nwanekezie et al. (2010) discussed the impacts of land use allocation in Nigeria. The study looked at the aim and objectives of land use allocation, the impacts of land-use allocation, approaches to urban land use allocation and typical land allocation to various uses. The study did not examine the effect of land-use succession on property value. Ogungbemi (2012) investigated factors influencing the change of use and its attendant problems. This study examined the arbitrary changes of urban residential to commercial uses, such as shopping and light industrial venture. However, this study did not examine the relationship between land use succession and property value. Hassan (2015) examined landuse succession and real estate transaction in Ilorin metropolis. The study did not consider the relationship between rental value and types of land use succession. Ogungbemi (2012) examined the factors influencing the change of use and its attendant problems. This study 
examined the arbitrary changes of urban residential to commercial uses, such as shopping and light industrial ventures to bring out salient factors that stimulate change in use and to address the same. Also, the study looked at the reasons and effects in terms of problems associated with this change of use with the impact and consequences of uses on the neighbourhood. However, this study did not examine the relationship between land use succession and property value.

Farinmade (2007) investigated the level of conversion of land use and their implications in Nigerian cities with a focus on Surulere Local Government, Lagos. The study looked at land-use conversion and also explained that Land use change patterns are the result of the complex interactions between man and his physical environment. The study did not determine the trend in the rental value of the property. Nwanekezie et al, (2010) examined the impact of land use allocation in Nigeria. The study looked at the aim and objectives of land use allocation, the impacts of land-use allocation, approaches to urban land use allocation and typical land allocation to various uses. The study recommended that adequate standard facilities and services be provided to make the residential function efficiently in modern society. The study did not examine the effect of land-use succession on property value. Oduwaye (2013) examined the urban planning implications of changing land use structure of metropolitan Lagos. The study identified planning instruments that influence land use but did not examine the effect of land-use succession on property value. From the above, it can be said that little or no focus has been given to the effect of land-use succession on property value. However, the effect of land-use succession on property value is very significant, hence this study.

For this study, Land use succession is defined as the change in the use of land different from its original state/use whether from its natural, planned or unplanned to another state/use. However, this change can be as a result of various factors. Such factor may be as a result of growth and development, government policy, highest and best use of land and people attitude toward the use of land among others.

\section{Land Use Succession}

In line with land-use succession, the meaning, theory and conception of succession are much broader. Looking at land use succession, the relevant literature makes distinctions between two types of succession, which is conversion and modification. Land conversion entails a change from one cover type to another which is different from the use last approved by the planning authority. Land modification entails changes of structure or function without an extensive change from one type to another. Land alterations are the outcomes of natural processes such as volcanic eruptions, climatic differences, changes in river paths or the sea level, among others. Nevertheless, most of the land-use succession of the present and the recent past are due to human activities, that is exploits of land for construction, production or settlement. More, in particular, land use (both deliberately, knowingly and inadvertently) changes land use in three ways: by transforming it, if not quantitatively altering its form without full conversion; alter the land cover, or else transforming it to a qualitatively diverse state; and sustaining it in its present form against accepted agents of succession (Meyer and Turner 1996; Briassoulis, 2015).

\section{Types of Land Use Successions}

The level of land use successions in an area varies. Successions may be total or partial. This reveals the extent of successions of uses in an area. The various types of successions which among others includes: residential-commercial, residential-institution, residentialrecreational and residential-others (Hassan, 2015). The various factors responsible for the 
nature of the successions include: increase in rent, economic benefits, social factors, strategic location, demand for land and inadequate land-use policies among others (Kabanze, 2003). The partial successions were in forms of the combination of residential units and offices, residential units and shops, religious centres and residential units and among others. The high intensity of commercial activities among other factors in an area could be responsible for the successions of most of the residential buildings into commercial uses. The successions could be from residential to commercial. In most cases, it may be due to the increased profitability of rent/leasing outing the units as commercial units as against its use for residential uses. This is because commercial uses attract the highest rent than residential. One can easily know that property alteration is a form of invasion and succession process and also it is a process of assigning the property to its highest and best use. Therefore, it is an economic of re-assigning property resources to the uses that are most advantageous (Oduwaye, 2013).

\section{Factors Responsible for Conversion of Property by the Property Owners}

The key factors that inspired property owner to convert their property from residential to commercial use are the increase in demand for commercial properties which serves as a key factor that made property owner change the use of their property. This is closely followed by an increase in commercial activities. These two factors closely tie together, as an increase in demand for commercial property, would also trigger an increase in commercial activities in any given location (Hassan, 2015). Meeting up with neighbourhood trend (competition) also serves as one of the reason for property owners to convert their property. Most of the property owners within the neighbourhood changed the use of their property from residential to commercial, in a bid to stay competitive and not feel left out. They tend to follow the trend of others in their neighbourhood (Nwanekezie et al. 2010). Also, most of the property owner seems to change the use of their property due to the need to optimize investment return or to meet up with current economic reality (Hassan, 2015). Furthermore, the increase in family size which invariably would make the property owners shoulder more responsibilities in the family also serves as another factor. The major pick based on the landlord's perspective is the fact that they largely respond to demand and following economic principles, which say the higher the demand, the higher the price, which has a contrary correlation with supply (Ogungbemi, 2012).

\section{Factors Determining Land Use Succession and Property Value}

From the literature factors that were identified that were correlate of land-use succession and determinant of property value include advances in technology, social-economic, cultural, environmental and physical requirements for space and location, economic benefits of land, increase in rent, social factors, strategic location, inadequate land-use policies, population pressures, household income, likely rents made from land uses, geographic, safety and security and land ownership characteristics. Characteristics of urban infrastructure that consist of a wide array of facilities and services, such as road, drainage, water, waste disposal, communication, primary health services, schools and housing attract high property value which eventually attracted occupant of the property and eventually influenced landuse change in a locality (Nwanekezie et al., 2010). Other factors that cause land-use succession according to literature are quality of neighbourhood and infrastructure, location and structural characteristics, accessibility factors, neighbourhood level factors, public services, taxes and density factors, structural, specific negative externalities, physical, neighbourhood and environmental quality, changes in fashion and taste, quality of the view, population (increase or decrease). Also, institutional factors (these are factors associated 
with people's culture, religious belief and government action), economic factors, technological factors, location and complementary uses (Ajibola et al. 2013).

\section{Concept of Property and Property Values}

The concept of property varies and has no particular or generally conventional definition. Different academic disciplines like economics, anthropology, law and sociology describe the concept more systematically. In general use, the property may perhaps be considered as simply one's own thing. Social scientists regard property as a bundle of rights and obligations. They further added that property is not a connection between people and things but a connection between people and things, and in law, it is often regarded as the rights of ownership, which may either be public or private property (Oni, 2008b). Property may be grouped into real property, tangible and intangible, real estate, immovable property, the estate in land, personal property, interests in land and improvements. Personal property refers to things that a person has an exclusive right to use which may be tangible such as cars, shoes, clothing and animals while intangible are stocks and bonds (N.I.E.S.V., 1985; Johnson, Davis and Shapiro, 2005). Real property in general law systems can be referred to land or any irremovable feature or construction above its surface or below it. Immovable property is anything or objects that cannot be moved such as premises, buildings, land goods and assets. Also, real estate is synonymous with real property otherwise known as immovable property; it is a legal term that comprises of land jointly with anything permanently attached to it (Oni, 2008a).

As regard market value which otherwise known as fair market value or fair value is the price at which an asset would exchange in a competitive arrangement. In differentiating between price and market value, a price is obtained for specific property under the specific transaction and may or may not represent the property's market value when special considerations such as a family relationship between the buyer and seller are present (Oni, 2008b). Property value, therefore, according to Millington cited in Ajibola et al. (2013) refers to money received from a person(s) ready and able to acquire property as soon as it is offered for sale by a willing and enthusiastic seller, bearing in mind the realistic time for negotiation and with the full awareness of the character and uses which the property is capable of being put.

\section{Trend in Property Value}

The trend is the general direction of the price of an asset. It is a series of relative changes which may be identified and projected into a probable future pattern. However, any consistent pattern or change in the general direction of the real estate industry which, over time, causes a statistically obvious change is otherwise referred to real estate trend. This trend can be a consequence of the economy, consumer speculations, a change in mortgage rates, or other fundamental and non-fundamental bases. Also, the trend in property value may be viewed from the angle of series of related changes which have taking among the various factors that determined trends in the value of property/properties over a particular period under consideration. Changes in capital or rental value of property depend on the general level of the economic situation of a particular Country under consideration at a particular point in time. Changes in capital or rental value of the property during boom, stability and recession period are often different (Harvey, 1996 and Reed and Crawford, 2014). 


\section{Determinants of Property Values}

Property value, whether its capital or rental is a crucial aspect of property markets worldwide and determined by a range of factor while the determination of those factors is an important part of property valuation. The variables that determined property values can be faction into; accessibility (location) variables, neighbourhood variables, environmental variables, and property variables as depicted in Figure 3 (Ajibola et al. 2013).

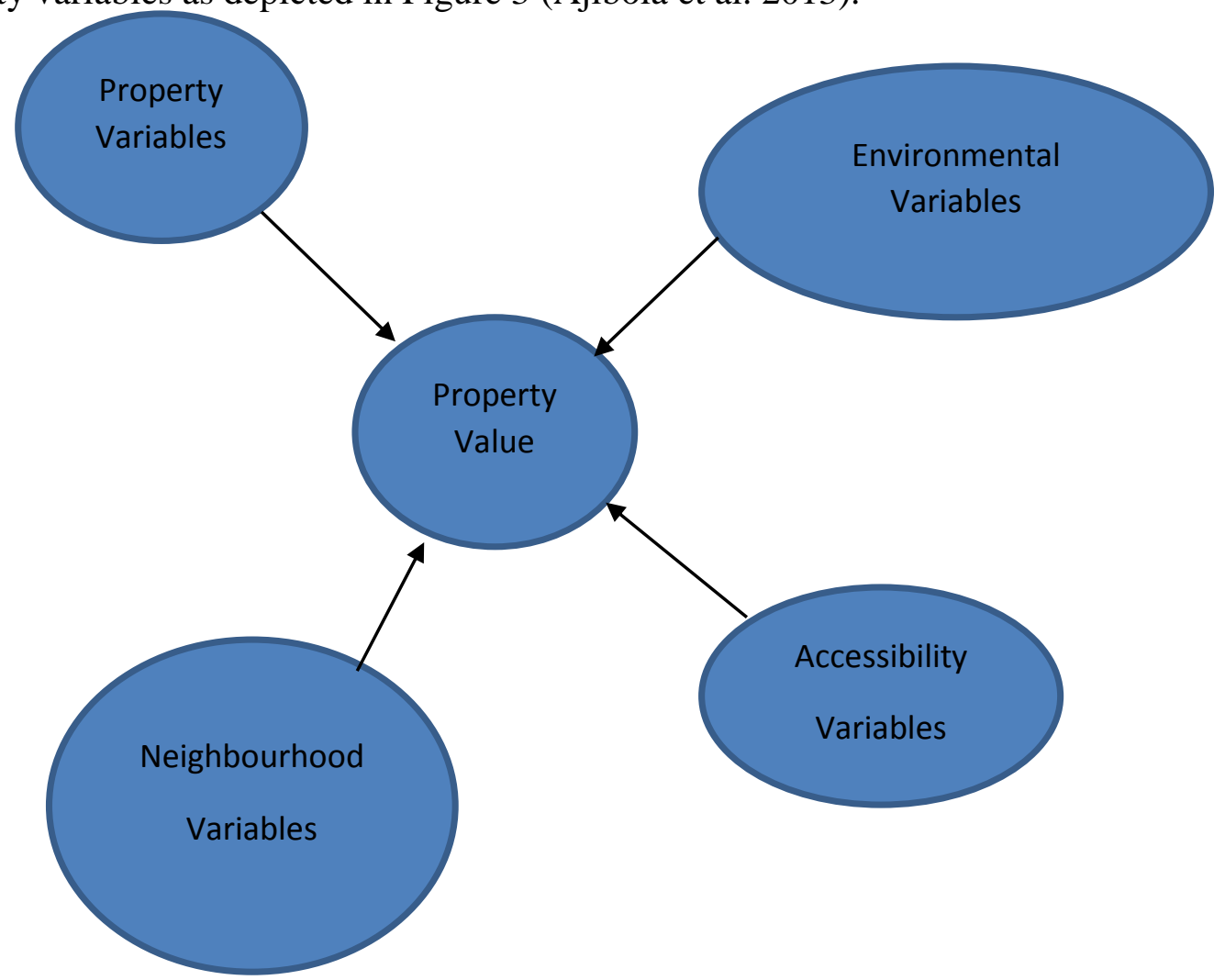

Figure 3. Factors Determining Property Values.

Source: Ajibola et al. (2013).

Location, structural characteristics, security, supply and demand factors have been regarded as a major determinant of property value. Security is important with tenant and visitor safety, location is imperative to nearness to the target market and sources of supplies; conditions and facilities are significant to attracting optimal rentals, and conversely, property's ability to generate income, in terms of demand and good location relative to its use is the major considerations for property value. Similarly, the cost in use, scarcity, state of the economy, government prospect of income growth and political factors, physical features and taxation are the determinants of property value. Other attributes of property value include accessibility factors, neighbourhood level factors, public services, taxes, specific negative externalities and density factors (Ajibola et al. 2013).

Tse and Love (2000) identified four categories of property value factors to comprise of physical, structural, environmental and neighbourhood. Similarly, Oyebanji (2003) recognised seven factors that affect property values, to include: increase or decrease in population, location, economic factors, institutional factors (these are factors relating to people's religious belief and culture, and government action), changes in taste and fashion, and complementary uses. Cloete and Chikafalimani (2001) categorised eight factors that influence property value, which are architectural design, quality of finishing, maintenance condition of the property, size of the property, security, condition of the street, and location. Also, factors that decide property values were classified, which comprise; effect of a high- 
speed mode of transportation infrastructural funding. Other factors identified comprises of accessibility to location-distance of land usages, changes in taste and fashion, political factor, institutional factor, planning regulation, economic factor, location, transportation, change in the population, complementary uses, road transport network, environmental quality, aesthetics, and growth pattern of land use (Oni, 2008b).

\section{Environmental Factors Affecting Properties Value}

The environmental factor is one of the factors accountable for the value of the property. The quality and condition of that environment affect the judgments made on the real estate and property market. This, however, affects and influences the value of the property and its physical, social and cultural popularity which generates economic benefits. The key environmental factors affecting property prices were greenery, surface water, noise impacts and landscape features (Cellmer, et al 2012). Other environmental factors affecting land use succession and properties value include networks; safety at town and neighbourhood level that include: Technical features (lighting and accessibly among others) and social characteristics of the areas. Air pollution is another important environmental factor that resulted from heavy traffic, proximity to manufacturing or other air-polluting plants and others. Also included was the noise; especially by aircraft and heavy traffic; soil pollution from toxic waste. Proximity to special uses is another issue that comprises; proximity to cemeteries, shopping malls among others. Also, building characteristics that include; building type, ages of the buildings, streets and buildings orientation, building forms, wall colour, window protection among others (Olayiwola, Adeleye and Oduwaye, 2006 and Makinde, 2019).

\section{RESEARCH METHOD}

Data for the research were from primary and secondary sources. Information was collected through field observation and the administration of questionnaires. The questionnaire was concentrated on retrieving the current and past trends of land use succession and rental value in the selected business areas where land-use succession is prevalent. Data collection were based on three (3) purposively selected busy roads in Ife Central LGA due to the high prevalence of land-use succession concentration in these areas. These include roads from Tollgate to Obafemi Awolowo Teaching Hospital Complex (OAUTHC), from Ede road to May-Fair round-about and Iremo road, comprising 305, 98 and 118 properties respectively. The sampling frame for Estate Surveyors and Valuer consisted of the seven (7) registered Estate Surveyors and Valuation firms based on Nigeria Institution of Estate Surveyors and Valuer (NIESV) directory 2016 and one Official from Town Planning and Land Services Department in Ile-Ife.

Table 1. Summary of Study Population, Sampling Frame, Size and Sampling Techniques

\begin{tabular}{|c|c|c|c|c|}
\hline S/No & Study Population & $\begin{array}{l}\text { Sampling } \\
\text { Frame }\end{array}$ & Sampling Size & Sampling Technique \\
\hline 1 & $\begin{array}{l}\text { Residential, Commercial and } \\
\text { Residential cum Commercial } \\
\text { buildings }\end{array}$ & 454 & 227 & $\begin{array}{l}\text { Systematic Sampling } \\
\text { Technique }\end{array}$ \\
\hline 2 & Estate Surveyors and Valuers & 7 & 7 & Purposive Sampling \\
\hline 3 & $\begin{array}{l}\text { Town Planning and Land } \\
\text { Services department } \\
\text { Total }\end{array}$ & $\begin{array}{l}1 \\
462\end{array}$ & $\begin{array}{l}1 \\
235\end{array}$ & Purposive Sampling \\
\hline
\end{tabular}

Table 2 illustrates the summary of land use in the study area while Table 3 clearly illustrates the percentage of land uses selected for sample in the selected busy roads. 
Table 2. Summary of Land Use in the Study Area

\begin{tabular}{lllll}
\hline s/no & Land uses & $\begin{array}{l}\text { Selected busy roads and Total no of property on both side of the roads } \\
\text { From Tollgate to }\end{array}$ & $\begin{array}{l}\text { From Ede road to May-Fair round- } \\
\text { about }\end{array}$ & $\begin{array}{l}\text { Iremo } \\
\text { road }\end{array}$ \\
\hline 1. & Residential & 24 & 16 & 18 \\
2. & Commercial & 204 & 56 & 52 \\
3. & Mixed uses & 34 & 14 & 36 \\
4. & Institutional & 12 & 2 & 3 \\
5 & Industrial & 2 & - & - \\
6 & Religious & 10 & 2 & 3 \\
7 & Others use & 19 & 8 & 6 \\
& Total & 305 & 98 & 118 \\
\hline
\end{tabular}

Table 3. No of Properties on Both Side of the Roads Selected For Sample in the Selected Busy Roads.

\begin{tabular}{lll}
\hline Selected Busy Roads & $\begin{array}{l}\text { Total no of Properties on } \\
\text { both side of the Roads }\end{array}$ & $\begin{array}{l}\mathbf{5 0} \% \text { Sampling } \\
\text { units }\end{array}$ \\
\hline From Tollgate to OAUTHC. & 262 & 131 \\
From Ede road to May-Fair round-about. & 86 & 43 \\
Iremo road & 106 & 53 \\
Total & 454 & 227 \\
\hline
\end{tabular}

A systematic sampling technique was employed in selecting respondents in the study area. After the first property with the said characteristics were selected at random, every other odd number of properties in the study area were selected, starting from the first property units in each of the business districts/roads involved. In each of the property selected, the landlords' or tenant were administered with the questionnaire. But where these categories of people are not available, a mature person that represents landlords' or tenant was selected.

\section{DATA ANALYSIS AND PRESENTATION}

After data had been sourced, it was subjected to analysis using statistical package for social sciences (SPSS 2016). Descriptive analytical techniques were employed in the analysis and presentation. Also, inferential statistical models such as linear regression analysis were used to test the relationship between two variables. Linear regression and analysis of variations (ANOVA) were also used to determine and described the form of the established relationship between the variables. Other tools include Microsoft Excel software that was used with polynomial order 2; R2 and trend line options selected to derive predictive models. Table 4 presents the response rate obtained from the field.

Table 4. Response Rate from the Field

\begin{tabular}{llllc}
\hline S/N & Respondents & $\begin{array}{l}\text { Number } \\
\text { Distributed }\end{array}$ & $\begin{array}{l}\text { Number } \\
\text { Retrieved }\end{array}$ & $\begin{array}{l}\text { Percentage } \\
(\boldsymbol{\%})\end{array}$ \\
\hline 1. & Town Planning and Land Services in Ile-Ife & 1 & 1 & 100 \\
2. & Estate Surveyors and Valuers & 7 & 7 & 100 \\
3. & Building occupiers & 227 & 204 & 90 \\
& Total & 235 & 212 & 91 \\
\hline
\end{tabular}

\section{Types of Land Use Succession in Ile-Ife}

The responses of Estate Surveyors and Valuers as contained in Table 5 shows that the commonest types of land use succession recorded in the area were succession from residential use to commercial use, this is contained in the responses $4(57.1 \%)$ of the respondents. Other successions experienced were: commercial to residential $1(14.3 \%)$ 
respondent, residential to recreational $1(14.3 \%)$ respondent, residential to religion $1(14.3 \%)$ respondent and Residential cum commercial 1 (14.3\%) respondent respectively. Also, the responses of Building Occupiers as contained in Table 5 shows that the common types of land use succession recorded in the area were succession from residential use to commercial use, this is contained in the responses of $162(79.4 \%)$ of the respondents. Other successions experienced were; residential to recreational $6(2.9 \%)$, residential to industrial $2(0.98 \%)$, residential to religion $6(2.9 \%)$, Residential cum commercial $20(9.8 \%)$ and others $8(3.9 \%)$ such as open space to commercial, set back to commercial, road enlargement among others. The responses from Official of Town Planning and Land Services Department as contained in Table 5 shows that the most common types of land use succession recorded in the study area were succession from residential use to commercial use. The Estate Surveyors and Valuers, Building Occupiers and Official of Town Planning and Land Services Department reported that residential to commercial land use succession was the most common type in the study area. This might be attributed to increased demand for commercial uses as a result of increased urbanisation and rising population in the study area.

Table 5. Types of Land use Succession

\begin{tabular}{lllllll}
\hline $\begin{array}{l}\text { The prevalent type of } \\
\text { Land use Succession }\end{array}$ & $\begin{array}{l}\text { Estate Surveyors } \\
\text { Valuers }\end{array}$ & \multicolumn{2}{l}{ Building Occupiers } & \multicolumn{3}{l}{$\begin{array}{l}\text { Town Planning and } \\
\text { Land Services } \\
\text { Department }\end{array}$} \\
& Frequency & $\mathbf{\%}$ & Frequency & \% & Frequency & \% \\
\hline Residential-commercial & 4 & 57.1 & 162 & 79.4 & 1 & 100 \\
Commercial - Residential & - & - & - & - & - & \\
Residential-Recreational & 1 & 14.3 & 6 & 2.9 & - & \\
Residential - Industrial & - & - & 2 & 0.98 & - & \\
Residential - Religion & 1 & 14.3 & 6 & 2.9 & - & \\
Residential cum & 1 & 14.3 & 20 & 9.8 & - & \\
Commercial & & & & & & \\
Others & - & - & 8 & 3.9 & - & 100 \\
TOTAL & 7 & 100 & 204 & 100 & 1 & \\
\hline
\end{tabular}

\section{Annual Types of Land use Succession between 2002 and 2016}

The Annual Types of land use succession in the study area was also examined from Official of Town Planning and Land Services department Ile-Ife. The finding in Table 6 and Figure 4 shows that land-use succession varies from one year to another. The result is that 269 $(49 \%)$ of the land-use succession in the study area was from residential to commercial, which increases from 4 to 22 between 2002 and 2010 and decreases from 20 to 18 between 2011 and 2012; while there was also an increase from 26 to 38 between 2013 and 2016. It can be reported that there was no commercial to residential land use succession between 2002 and 2004, while in 2005, 2008 and 2013 there were only $3(0.55 \%)$ commercial to residential land use succession, 1 each, that took place in each year. None took place in 2006, 2007, 2009, 2010, 2011, 2012, 2014, 2015 and 2016 in the study area.

The study shows that $252(45.9 \%)$ mixed-use (residential cum commercial) land-use succession. There was an increase from 3 to 12 between 2002 and 2006, while there was a decrease from 12 to 10 in 2007. Also, it increases from 10 to 35 between 2008 and 2016 in the study area. Also, the study shows that there was no residential to industrial land use succession in the study area between 2002 and 2005. In 2006 and 2010, only 2 (0.36\%), 1 in each year residential to industrial land use succession occurred, and none between 2007 and 2009 and also, between 2011 and 2016. The result also shows that there were 20 (3.6\%) residential to religion land-use succession in the study area between 2002 and 2016. 
Table 6. Annual Types of Land use Succession between 2002 and 2016

\begin{tabular}{|c|c|c|c|c|c|c|c|c|}
\hline \multirow[t]{2}{*}{ Years } & \multicolumn{6}{|c|}{ Land Use Succession Types in the Study Area } & \multirow{2}{*}{$\begin{array}{l}\text { Total } \\
\text { number } \\
\text { of LUS }\end{array}$} & \multirow{2}{*}{$\begin{array}{l}\text { percentage } \\
\text { of the total } \\
\text { number of } \\
\text { LUS }\end{array}$} \\
\hline & $\begin{array}{l}\text { Residential- } \\
\text { commercial }\end{array}$ & $\begin{array}{l}\text { Commercial } \\
\text {-Residential }\end{array}$ & $\begin{array}{l}\text { ( Residential } \\
\text { Cum } \\
\text { Commercial) }\end{array}$ & $\begin{array}{l}\text { Residential- } \\
\text { industrial }\end{array}$ & $\begin{array}{l}\text { Residential- } \\
\text { Religion }\end{array}$ & $\begin{array}{l}\text { Residential- } \\
\text { Recreation }\end{array}$ & & \\
\hline 2002 & 4 & - & 3 & - & 3 & - & 10 & 1.82 \\
\hline 2003 & 6 & - & 5 & - & 2 & - & 13 & 2.37 \\
\hline 2004 & 9 & 1 & 8 & - & 2 & - & 20 & 3.64 \\
\hline 2005 & 9 & - & 8 & - & 2 & 1 & 20 & 3.64 \\
\hline 2006 & 10 & - & 12 & 1 & 1 & - & 24 & 4.37 \\
\hline 2007 & 11 & - & 10 & - & 1 & - & 22 & 4.01 \\
\hline 2008 & 14 & 1 & 15 & - & 1 & - & 31 & 5.65 \\
\hline 2009 & 18 & - & 14 & - & 1 & - & 33 & 6.01 \\
\hline 2010 & 22 & - & 18 & 1 & 1 & 1 & 43 & 7.83 \\
\hline 2011 & 20 & - & 22 & - & 1 & - & 43 & 7.83 \\
\hline 2012 & 18 & - & 22 & - & 1 & - & 41 & 7.47 \\
\hline 2013 & 26 & 1 & 24 & - & 1 & 1 & 53 & 9.65 \\
\hline 2014 & 30 & - & 26 & - & 1 & - & 57 & 10.38 \\
\hline 2015 & 34 & - & 30 & - & 1 & - & 65 & 11.84 \\
\hline 2016 & 38 & - & 35 & - & 1 & - & 74 & 13.48 \\
\hline Total & 269 & 3 & 252 & 2 & 20 & 3 & 549 & 100 \\
\hline Percentage & 49.0 & 0.55 & 45.9 & 0.36 & 3.6 & 0.55 & 100 & \\
\hline
\end{tabular}

Source: Town Planning and Land Services Department (2017)

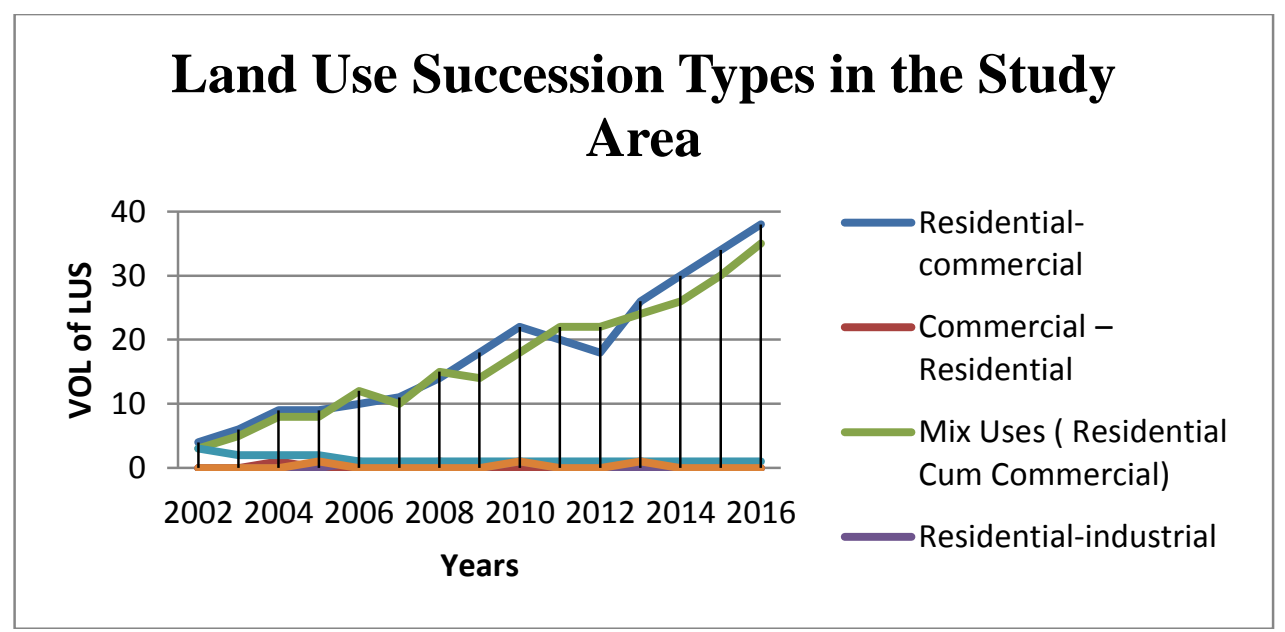

Figure 4. Land use Succession Types in the Study Area.

Trend in Letting Transactions between the Year 2002 and 2016 in the Study Area

The study determines the trend in property rental value between the year 2002 and 2016 in the study area. It examines the trend in rental values using the volume of letting transaction records from Estate Surveyors in the study area between the year 2002 and 2016 in determining the models for predicting rental values in the study area.

Table 7 contained the number of letting transactions of properties effectively carried out by Estate Surveying Firms in the past fifteen years in the study area. For 1 bedroom, the total volume of letting transactions between 2002 and 2016 were $627(10.27 \%)$ transactions, for 2 bedrooms was $365(6.2 \%)$ transactions, for 3 bedrooms were $216(3.7 \%)$ transactions and for corporate office were 753 (12.8) transactions. Also, for Single Room (Mud House) were 402 (6.9) transactions, for Single Room (Brick House) were 378 (6.4) transactions, for Single Shop (Mud Shop) were 1630 (27.8) transactions and for Single Shop (Brick Shop) were 1491 (25.4\%) transactions. Property with the highest volume of the transaction was Single Shop (Mud Shop) with 1630 (27.8\%) transactions, while the least was 3 bedrooms with 216 (3.7\%) transactions. Also, the total volume of letting transactions of properties was 5862 $(100 \%)$. The trend of letting transactions of properties increased from 2002 to 2016 respectively. 
Table 7. Volume of Letting Transactions of Properties

\begin{tabular}{|c|c|c|c|c|c|c|c|c|c|c|c|}
\hline $\mathbf{S} / \mathbf{N}$ & Years & $\begin{array}{l}1 \text { Bed- } \\
\text { room }\end{array}$ & $\begin{array}{l}\text { 2Bed- } \\
\text { room }\end{array}$ & $\begin{array}{l}\text { 3Bed- } \\
\text { room }\end{array}$ & $\begin{array}{l}\text { Office } \\
\text { Space } \\
\text { Rent } /^{2} \\
\text { M }\end{array}$ & $\begin{array}{l}\text { Single } \\
\text { Room } \\
\text { (Mud } \\
\text { House) }\end{array}$ & $\begin{array}{l}\text { Single } \\
\text { Room } \\
\text { (Brick } \\
\text { House) }\end{array}$ & $\begin{array}{l}\text { Single } \\
\text { Shop } \\
\text { (Mud } \\
\text { Shop) }\end{array}$ & $\begin{array}{l}\text { Single } \\
\text { Shop } \\
\text { (Brick } \\
\text { Shop) }\end{array}$ & $\begin{array}{l}\text { Total } \\
\text { Volume of } \\
\text { Transaction } \\
\text { s of all } \\
\text { Properties }\end{array}$ & $\begin{array}{l}\text { Percentage } \\
\text { of Total } \\
\text { Volume of } \\
\text { Transaction } \\
\text { s of all } \\
\text { Properties }\end{array}$ \\
\hline 1. & 2002 & 58 & 38 & 24 & 42 & 50 & 41 & 59 & 49 & 361 & 6.2 \\
\hline 2. & 2003 & 52 & 30 & 20 & 44 & 42 & 37 & 62 & 53 & 340 & 5.8 \\
\hline 3. & 2004 & 50 & 28 & 18 & 41 & 37 & 36 & 68 & 65 & 343 & 5.9 \\
\hline 4. & 2005 & 50 & 32 & 18 & 38 & 30 & 34 & 76 & 66 & 344 & 5.9 \\
\hline 5. & 2006 & 47 & 20 & 16 & 45 & 26 & 31 & 79 & 68 & 332 & 5.7 \\
\hline 6. & 2007 & 46 & 22 & 15 & 35 & 36 & 30 & 85 & 83 & 352 & 6.0 \\
\hline 7. & 2008 & 44 & 24 & 18 & 34 & 40 & 15 & 96 & 88 & 359 & 6.1 \\
\hline 8. & 2009 & 42 & 28 & 16 & 28 & 24 & 29 & 102 & 92 & 361 & 6.2 \\
\hline 9. & 2010 & 40 & 33 & 15 & 48 & 24 & 27 & 110 & 101 & 398 & 6.8 \\
\hline 10 & 2011 & 38 & 38 & 13 & 54 & 21 & 23 & 121 & 111 & 419 & 7.1 \\
\hline 11 & 2012 & 38 & 18 & 10 & 62 & 20 & 21 & 132 & 119 & 420 & 7.2 \\
\hline 12 & 2013 & 32 & 15 & 10 & 77 & 17 & 21 & 145 & 135 & 452 & 7.7 \\
\hline 13 & 2014 & 30 & 15 & 09 & 68 & 15 & 15 & 153 & 143 & 448 & 7.6 \\
\hline 14 & 2015 & 32 & 14 & 08 & 62 & 11 & 11 & 165 & 151 & 454 & 7.7 \\
\hline \multirow[t]{4}{*}{15} & 2016 & 28 & 10 & 06 & 75 & 09 & 07 & 177 & 167 & 479 & 8.2 \\
\hline & Total & 627 & 365 & 216 & 753 & 402 & 378 & 1630 & 1491 & 5862 & 100 \\
\hline & $\begin{array}{l}\text { Volume } \\
\text { of Tran- } \\
\text { sactitions }\end{array}$ & & & & & & & & & & \\
\hline & Prcentage & 10.7 & 6.2 & 3.7 & 12.8 & 6.9 & 6.4 & 27.8 & 25.4 & 100 & \\
\hline
\end{tabular}

\section{Regression Analysis of Total Letting Transactions}

Table 7 shows the minimum volume of transactions recorded in 2006 with 332 transactions and the maximum was recorded in 2016 with 479 transactions. The general effect of land use succession on the total volume of transactions is based on the computed summation of $\mathrm{R}^{2}=0.853$ within 15 years, which shows that there was a significant decrease in the volume of rental property transactions from 361 in 2002 to 332 in 2006 while from 2007 there was a significant increase in the volume of rental properties transactions from 352 in 2007 to 479 in 2016. The commercial land uses were having the highest transactions with 3,874 (66\%) transactions in the market within the same period while the residential land uses were having the least transactions with 1988 (34\%) transactions in the market within the same period. From Table 8 and Figure 5, the coefficient of the graph is $\mathrm{Y}=10.371 \mathrm{x}+307.829$, where $\mathrm{Y}$ is the total annual volumes of lease and $\mathrm{x}$ is the time (years). The trend had a positive slope of 10.371 indicating for 2002 to 2016 . The total annual volume of transactions increased, by 10.371 per unit change in time. The $\mathrm{R}-$ square value equals 0.853 , which was a good fit. The closer this value to 1 the better the line fits the data. The trend line gives an idea of which direction the volume of letting transactions is going.

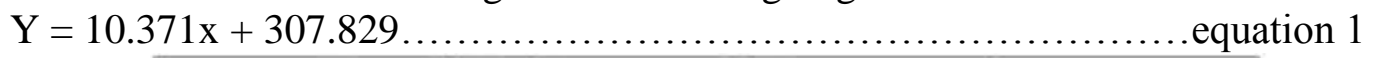

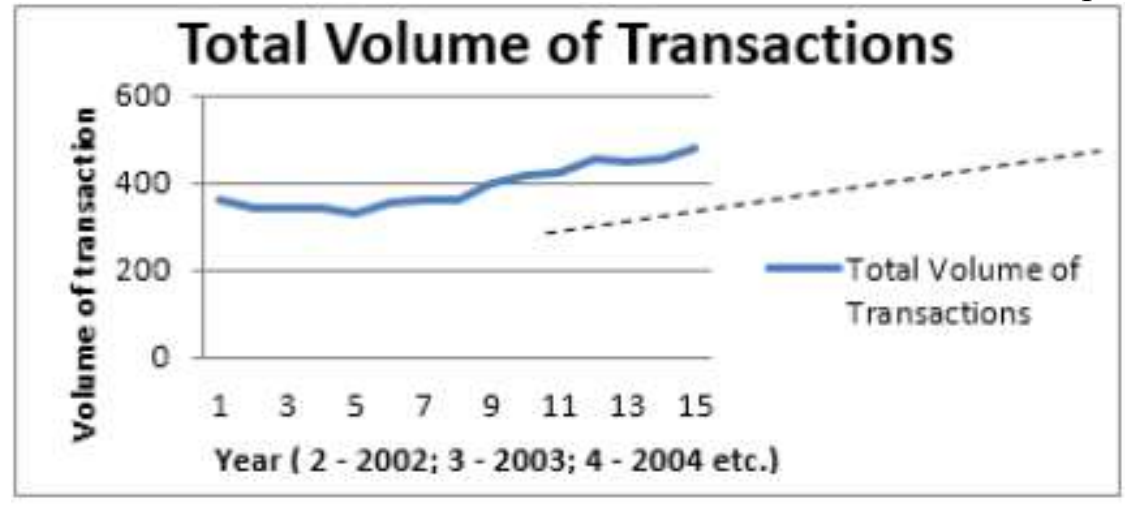

Figure 5. Total Transactions in the Study Area (2002 - 2016) 
Table 8. Regression Analysis of Total Letting Transactions

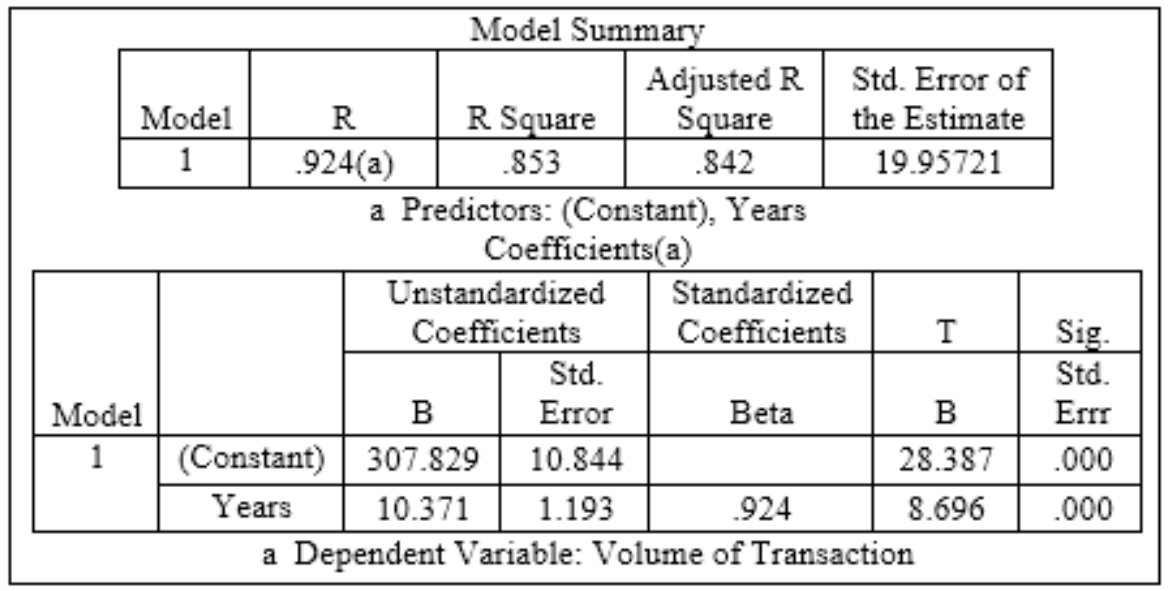

\section{Trend in Rental Values between the Year 2002 and 2016 in the Study Area}

The study obtained the annual rental values from Estate surveying Firms in respect of different categories of properties in the study area for the period between 2002 and 2016. The analysis is contained in Table 9. The result shows that 3 bedrooms flat had the highest rental value with $\$ 1,208,000$ (23.29\%) and least rental value is Single Room (Mud House) with $\$ 286,000(5.51 \%)$. The trend of the rental value of properties increased from 2002 to 2016.

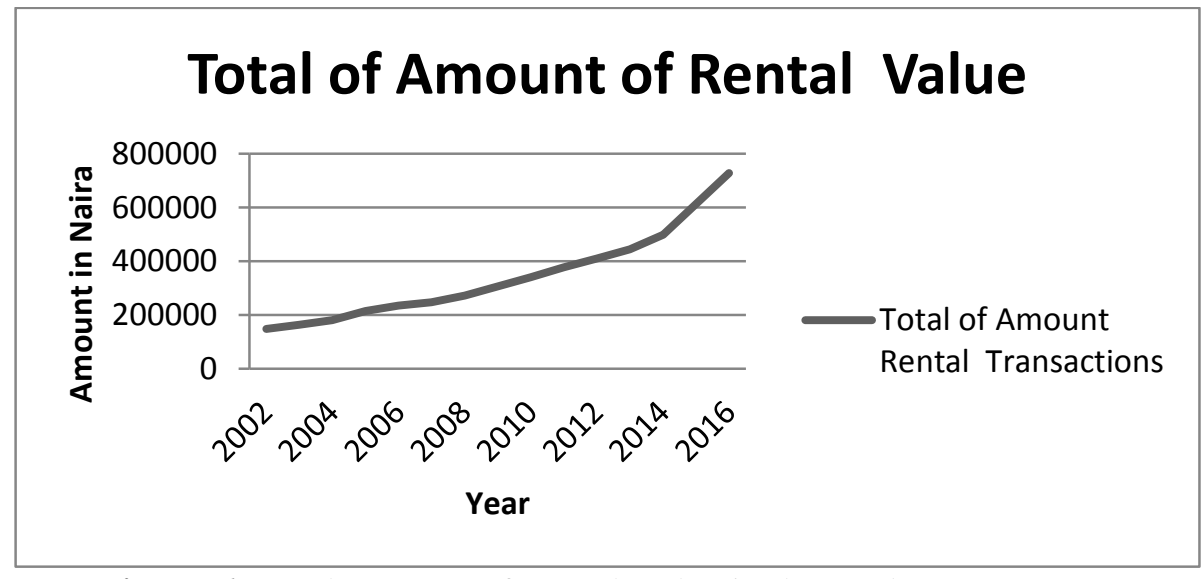

Figure 6. Total Amount of Rental Value in the Study Area (2002 -2016)

Table 9. Trend in Rental Values between the Year 2002 and 2016 in the Study Area

\begin{tabular}{|c|c|c|c|c|c|c|c|c|c|c|c|}
\hline $\mathbf{S} / \mathbf{N}$ & Years & $\begin{array}{l}1 \\
\text { Bedroom } \\
\text { Flat } \\
N\end{array}$ & $\begin{array}{l}2 \\
\text { Bedroom } \\
\text { Flat } \\
\#\end{array}$ & $\begin{array}{l}3 \\
\text { Bedroom } \\
\text { Flat } \\
N\end{array}$ & $\begin{array}{l}\text { Corpor } \\
\text { ate } \\
\text { Office } \\
\text { Rent } /^{2} \\
M \neq N\end{array}$ & $\begin{array}{l}\text { Single } \\
\text { Room } \\
\text { (Mud } \\
\text { House) } \\
\end{array}$ & $\begin{array}{l}\text { Single } \\
\text { Room } \\
\text { (Brick } \\
\text { House) } \\
\mathbb{N}\end{array}$ & $\begin{array}{l}\text { Single } \\
\text { Shop } \\
\text { (Mud } \\
\text { Shop) } \\
\end{array}$ & $\begin{array}{l}\text { Single } \\
\text { Shop } \\
\text { (Brick } \\
\text { Shop) } \\
\ldots\end{array}$ & $\begin{array}{l}\text { Total } \\
\text { Amo- } \\
\text { unt of } \\
\text { Rental } \\
\text { Value } \\
\mathrm{N}\end{array}$ & $\begin{array}{l}\text { Percenta } \\
\text { ge of } \\
\text { Total } \\
\text { Amount } \\
\text { of } \\
\text { Rental } \\
\text { Value }\end{array}$ \\
\hline 3. & 2004 & 15000.00 & 35000.00 & 45000.00 & 30000.00 & 10000.00 & 15000.00 & 15000.00 & 16000.00 & 181000 & 3.49 \\
\hline 4. & 2005 & 30000.00 & 38000.00 & 48000.00 & 35000.00 & 13000.00 & 18000.00 & 15000.00 & 18000.00 & 215000 & 4.14 \\
\hline 5. & 2006 & 35000.00 & 40000.00 & 52000.00 & 36000.00 & 14000.00 & 24000.00 & 16000.00 & 18000.00 & 235000 & 4.53 \\
\hline 6. & 2007 & 40000.00 & 45000.00 & 55000.00 & 36000.00 & 14000.00 & 24000.00 & 16000.00 & 18000.00 & 248000 & 4.78 \\
\hline 7. & 2008 & 45000.00 & 48000.00 & 60000.00 & 40000.00 & 16000.00 & 28000.00 & 18000.00 & 18000.00 & 273000 & 5.26 \\
\hline
\end{tabular}




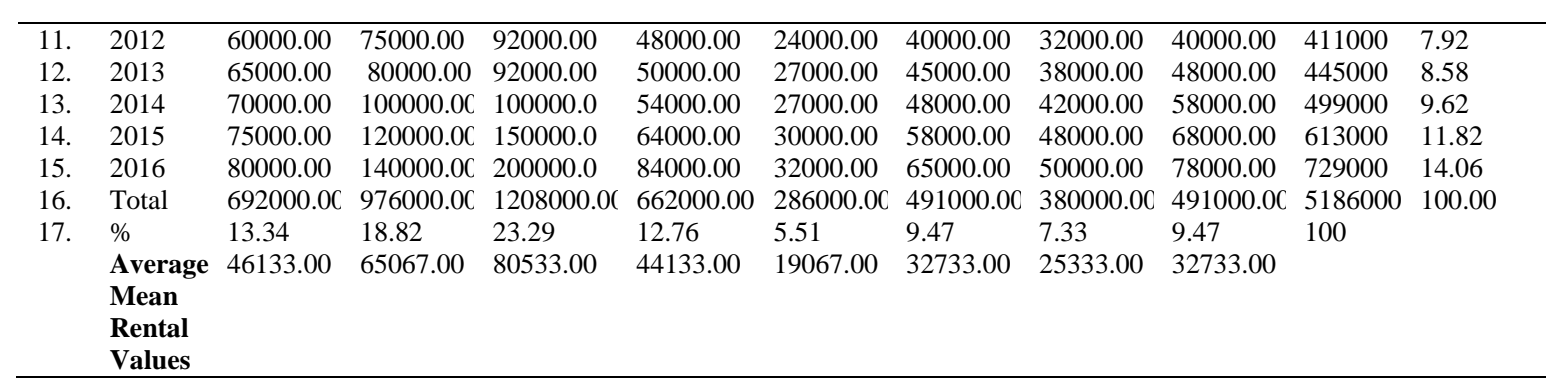

\section{Regression Analysis of Total Amount of Rental Value in the Study Area}

Table 9 shows the total amount of average rental value that was recorded between 2002 and 2016 with $\$ 5,186,000$. While Table 7 shows the total amount of average rental transaction. The general implication of land use succession on the total amount of average rental transaction and the rental value was based on the computed summation of $\mathrm{R}^{2}=0.911$ within 15 years which shows that there was a significant increase in the amount of average rental value between 2002 and 2016 from 148,000 to 729,000.

Table 10, shows that commercial land uses which include corporate office; single shop (mud shop) and single shop (brick shop) was having the highest average amount of rental value between 2002 and 2016 with 57.8\% while residential land uses which include, 1 bedroom; 2 bedrooms, 3 bedrooms, single room (mud house) and single room (mud house) was having an average amount of rental value with $42.2 \%$ in the study area within the same period.

Table 11 and Figure 6, shows that the coefficient of the graph is $\mathrm{Y}=36164.286 \mathrm{x}+$ 56419.048 , where $\mathrm{Y}$ is the total annual amount of average rental value and $\mathrm{x}$ is the time (years). The trend had a positive slope of 36164.286 indicating over the period between 2002 and 2016. The amount of rental value increased by 36164.286 per unit change in time and $R$ - square value equals 0.911, which is a good fit. The closer this value to 1 the better the line fits the data. The trend line gives an idea of which direction the rental value is going.

$\mathrm{Y}=36164.286 \mathrm{x}+56419.048$ .equation 2

The rental value of commercial and residential properties increases between 2002 and 2016 in the study area. The reason for the increase in value may be linked to the relative peace that has returned to the study area.

Table 10. Average Rental Value between 2002 and 2016

\begin{tabular}{|c|c|c|c|c|c|c|c|c|c|c|}
\hline $\mathbf{S} / \mathbf{N}$ & $\begin{array}{l}\text { Rental } \\
\text { Transactions }\end{array}$ & $\begin{array}{l}1 \\
\text { Bedroom }\end{array}$ & $\begin{array}{l}2 \\
\text { Bedroom }\end{array}$ & $\begin{array}{l}3 \\
\text { Bedroom }\end{array}$ & $\begin{array}{l}\text { Corporate } \\
\text { Office } \\
\text { Rent }{ }^{2} \mathrm{M}\end{array}$ & $\begin{array}{l}\text { Single } \\
\text { Room } \\
\text { (Mud } \\
\text { House) }\end{array}$ & $\begin{array}{l}\text { Single } \\
\text { Room } \\
\text { (Brick } \\
\text { House) }\end{array}$ & $\begin{array}{l}\text { Single } \\
\text { Shop } \\
\text { (Mud } \\
\text { Shop) }\end{array}$ & $\begin{array}{l}\text { Single } \\
\text { Shop } \\
\text { (Brick } \\
\text { Shop) }\end{array}$ & TOTAL \\
\hline 1. & $\begin{array}{l}\text { Total } \\
\text { Volume of } \\
\text { Transactions }\end{array}$ & 627 & 365 & 216 & 753 & 402 & 378 & 1630 & 1491 & 5862 \\
\hline 2. & $\begin{array}{l}\text { Average } \\
\text { Rental } \\
\text { Values }\end{array}$ & 46133.00 & 65067.00 & 80533.00 & 44133.00 & 19067.00 & 32733.00 & 25333.00 & 32733.00 & 345732 \\
\hline 3. & $\begin{array}{l}\text { Total } \\
\text { Amount of } \\
\text { Rental } \\
\text { value }\end{array}$ & 28925391 & 23749455 & 17395128 & 33232149 & 7664934 & 12373074 & 41292790 & 48804903 & 213437824 \\
\hline 4. & Percentage & 13.6 & 11.1 & 8.2 & 15.6 & 3.6 & 5.8 & 19.3 & 22.9 & 100 \\
\hline
\end{tabular}


Table 11. Regression analysis of Total Amount of Rental Value in the Study Area $(2002-2016)$

\begin{tabular}{|c|c|c|c|c|c|c|c|c|}
\hline & \multicolumn{7}{|c|}{ Model Summary } & \\
\hline & Model & $\mathrm{R}$ & R Square & \multicolumn{2}{|c|}{$\begin{array}{l}\text { Adjusted R } \\
\text { Square }\end{array}$} & \multicolumn{2}{|c|}{$\begin{array}{l}\text { Std. Error of the } \\
\text { Estimate }\end{array}$} & \\
\hline & 1 & $.954^{\mathrm{a}}$ & .911 & \multicolumn{2}{|c|}{.904} & \multicolumn{2}{|c|}{52448.78542} & \\
\hline & \multicolumn{7}{|c|}{ a. Predictors: (Constant), Years } & \\
\hline \multicolumn{9}{|c|}{ Coefficients $^{\mathrm{a}}$} \\
\hline \multirow{2}{*}{\multicolumn{2}{|c|}{ Model }} & \multicolumn{3}{|c|}{ Unstandardized Coefficients } & \multirow{2}{*}{\multicolumn{2}{|c|}{$\begin{array}{c}\text { Standardized } \\
\text { Coefficients } \\
\text { Beta }\end{array}$}} & \multirow[t]{2}{*}{$\mathrm{T}$} & \multirow[t]{2}{*}{ Sig. } \\
\hline & & B & Std. E & & & & & \\
\hline \multirow{3}{*}{1} & (Constant) & 56419.04 & 28498 & & & & 1.980 & .069 \\
\hline & Years & 36164.28 & 3134. & & & & 11.538 & .000 \\
\hline & \multicolumn{8}{|c|}{ a. Dependent Variable: Rental values } \\
\hline
\end{tabular}

\section{Relationship between Rental Value and Types of Land Use Succession}

In determining the relationship between rentals values (dependent variable) and residentialcommercial (independent variable) linear regression analysis was used. Table 12 shows Analysis of Variation (ANOVA) of the relationship between rental values and the independent variables (residential-commercial) that shows the P-values of 0.00 that was less than 0.05 , indicating that there was a statistically significant relationship between rental values and residential-commercial types of land use succession in the study area. The less closely this value to 0.05 the better the relationship. The $\mathrm{R}$ Square value was 0.953 . It can be observed that there was a positive relationship between the explanatory variables and rental values. However, change in the use of land from residential use to commercial use affects rental value. Residential-commercial types of land use succession increased the rental value in the study area.

Table 12. Regression Analysis Showing the Relationship between Rental Values and

Types of Land Use Succession in the Study Areas

1. Regression analysis between rental values and residential-commercial type of land use succession Model Summary

\begin{tabular}{|c|c|c|c|c|}
\hline Model & $\mathrm{R}$ & R Square & $\begin{array}{c}\text { Adjusted R } \\
\text { Square }\end{array}$ & $\begin{array}{c}\text { Std. Error of the } \\
\text { Estimate }\end{array}$ \\
\hline 1 & $.976(\mathrm{a})$ & .953 & .949 & 2.34852 \\
\hline \multicolumn{4}{|c}{ a Predictors: (Constant), Rental value }
\end{tabular}

$\operatorname{ANOVA}(\mathbf{b})$

\begin{tabular}{|c|c|c|c|c|c|c|}
\hline & & & & & & \\
Model & & Sum of Squares & Df & Mean Square & F & Sig. \\
\hline 1 & Regression & 1443.231 & 1 & 1443.231 & 261.666 & $.000(\mathrm{a})$ \\
\hline & Residual & 71.702 & 13 & 5.516 & & \\
\hline & Total & 1514.933 & 14 & & & \\
\hline
\end{tabular}

b Dependent Variable: Residential-commercial

2. Regression analysis between rental values and commercial-residential type of land use succession

\begin{tabular}{|c|c|c|c|c|}
\hline \multicolumn{5}{|c|}{ Model Summary } \\
\hline Model & $\mathrm{R}$ & R Square & $\begin{array}{c}\text { Adjusted R } \\
\text { Square }\end{array}$ & $\begin{array}{c}\text { Std. Error of the } \\
\text { Estimate }\end{array}$ \\
\hline 1 & $.141(\mathrm{a})$ & .020 & -.056 & .42539 \\
\hline \multicolumn{5}{|c|}{ a Predictors: (Constant), Rental value }
\end{tabular}




\begin{tabular}{|c|c|c|c|c|c|c|}
\hline \multicolumn{8}{|c|}{ ANOVA(b) } \\
\hline \multirow{3}{*}{ Model } & & $\begin{array}{c}\text { Sum of } \\
\text { Squares }\end{array}$ & Df & Mean Square & F & Sig. \\
\hline 1 & Regression & .048 & 1 & .048 & .263 & $.617(\mathrm{a})$ \\
\cline { 2 - 7 } & Residual & 2.352 & 13 & .181 & & \\
\cline { 2 - 7 } & Total & 2.400 & 14 & & \\
\hline \multicolumn{7}{|c|}{ b Predictors: (Constant), Rental value } \\
\hline
\end{tabular}

3. Regression analysis between rental values and mix uses (residential cum commercial) type of land use succession

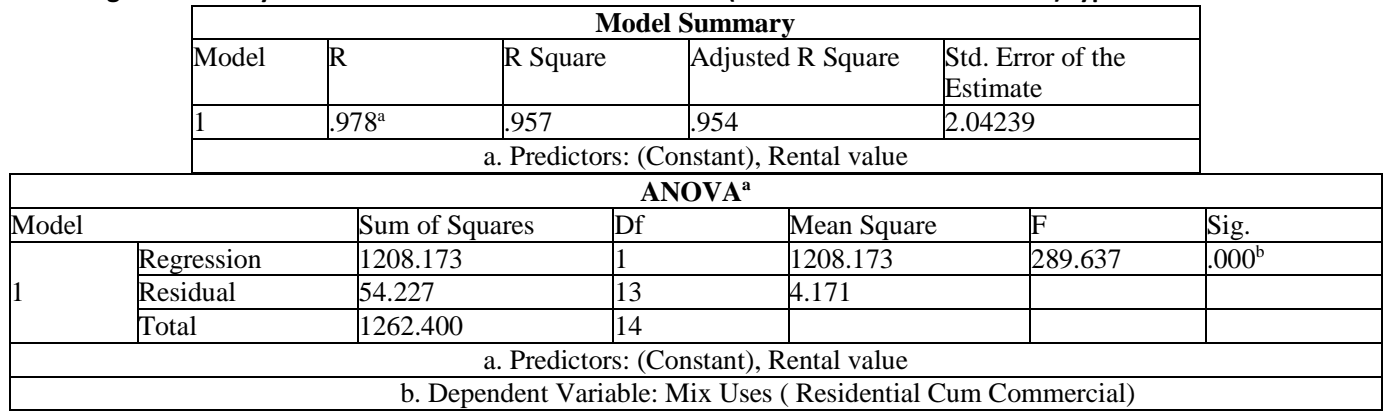

4. Regression analysis between rental values and residential-industrial type of land use succession

\begin{tabular}{|c|c|c|c|c|}
\hline \multicolumn{5}{|c|}{ Model Summary } \\
\hline Model & $\mathrm{R}$ & R Square & Adjusted R Square & $\begin{array}{c}\text { Std. Error of the } \\
\text { Estimate }\end{array}$ \\
\hline 1 & $.140^{\mathrm{a}}$ & .019 & -.056 & .36158 \\
\hline \multicolumn{5}{|c|}{ a. Predictors: (Constant), Rental value } \\
\hline
\end{tabular}

\begin{tabular}{|c|c|c|c|c|c|c|}
\hline \multicolumn{2}{|c|}{ ANOVA $^{\mathrm{a}}$} \\
\hline \multirow{3}{*}{ Model } & Sum of Squares & Df & Mean Square & F & Sig. \\
\hline \multirow{7}{*}{1} & Regression & .034 & 1 & .034 & .258 & $.620^{\mathrm{b}}$ \\
\cline { 2 - 7 } & Residual & 1.700 & 13 & .131 & & \\
\cline { 2 - 7 } & Total & 1.733 & 14 & & & \\
\hline \multicolumn{7}{|c|}{ a. Predictors: (Constant), Rental value } \\
\hline
\end{tabular}

5. Regression analysis between rental values and residential-religion type of land use succession

\begin{tabular}{|l|l|l|l|l|}
\hline \multicolumn{5}{|c|}{ Model Summary } \\
\hline Model & $\mathrm{R}$ & R Square & $\begin{array}{l}\text { Adjusted R } \\
\text { Square }\end{array}$ & $\begin{array}{l}\text { Std. Error of the } \\
\text { Estimate }\end{array}$ \\
\hline 1 & $.596^{\mathrm{a}}$ & .355 & .306 & .51431 \\
\hline \multicolumn{5}{|c|}{ a. Predictors: (Constant), Rental value } \\
\hline
\end{tabular}

\begin{tabular}{|c|c|c|c|c|c|c|}
\hline \multicolumn{7}{|c|}{$\mathrm{ANOVA}^{\mathrm{a}}$} \\
\hline Model & & Sum of Squares & $\mathrm{Df}$ & Mean Square & $\mathrm{F}$ & Sig. \\
\hline \multirow{3}{*}{1} & Regression & 1.895 & 1 & 1.895 & 7.162 & $.019^{\mathrm{b}}$ \\
\hline & Residual & 3.439 & 13 & .265 & & \\
\hline & Total & 5.333 & 14 & & & \\
\hline \multicolumn{7}{|c|}{ a. Predictors: (Constant), Rental value } \\
\hline \multicolumn{7}{|c|}{ b. Dependent Variable: Residential-Religion } \\
\hline
\end{tabular}

6. Regression analysis between rental values and residential-recreation type of land use succession

\begin{tabular}{|l|l|l|l|l|}
\hline \multicolumn{5}{|c|}{ Model Summary } \\
\hline Model & $\mathrm{R}$ & R Square & Adjusted R Square & $\begin{array}{l}\text { Std. Error of the } \\
\text { Estimate }\end{array}$ \\
\hline 1 & $.112^{\mathrm{a}}$ & .013 & -.063 & .36285 \\
\hline \multicolumn{5}{|c|}{ a. Predictors: (Constant), Rental value } \\
\hline
\end{tabular}




\begin{tabular}{|l|l|l|l|l|l|l|}
\hline \multicolumn{7}{|c|}{ ANOVA $^{\text {a }}$} \\
\hline \multirow{2}{*}{ Model } & Sum of Squares & Df & Mean Square & F & Sig. \\
\hline \multirow{6}{*}{1} & Regression & .022 & 1 & .022 & .165 & $.691^{\text {b }}$ \\
\cline { 2 - 7 } & Residual & 1.712 & 13 & .132 & & \\
\cline { 2 - 6 } & Total & 1.733 & 14 & & & \\
\hline \multicolumn{6}{|c|}{ a. Predictors: (Constant), Rental value } \\
\hline
\end{tabular}

The results on the relationship between rentals values and commercial - residential shows the P-values of 0.617 that was greater than 0.05 , indicating that there was no statistically significant relationship between rental values and commercial-residential types of land use succession in the study area. The R Square value is 0.020 . It can be observed that there was a negative relationship between the explanatory variables and rental values. However, change in the use of land from commercial use to residential use does not have an effect on rental value in the study area. The results on the relationship between rental values and the independent variables (mix uses) shows the P-values of 0.000 that was less than 0.05 , indicating that there was a statistically significant relationship between rental values and mix uses (residential cum commercial) types of land use succession in the study area. The $R$ Square value was 0.957 .

The results on the relationship between rental values and the independent variables (residential-industrial) that shows the P-values of 0.620 that was greater than 0.05 , indicating that there was no statistically significant relationship between rental values and residentialindustrial types of land use succession in the study area. The R Square value was 0.019. The results on the relationship between rental values and the independent variables (residentialreligion) that shows the P-values of 0.019 that was less than 0.05 , indicating that there was a statistically significant relationship between property values and residential-religion types of land use succession in the study area. The R Square value is 0.355. Residential-religion types of land use succession increased the rental value in the study area.

The results on the relationship between rental values and the independent variables (residential-recreational) that shows the P-values of 0.691 that was greater than 0.05 , indicating that there was no statistically significant relationship between rental values and residential-recreational types of land use succession in the study area. The $\mathrm{R}$ Square value is 0.013. It can be observed that there was a negative relationship between the explanatory variables and rental values. However, change in the use of land from residential use to recreation use does not have an effect on rental value in the study area.

\section{CONCLUSION}

Information obtained from the study shows that the values of rental properties increased both in commercial and residential properties between the year 2002 and 2016. Among the various type of land use succession, the residential-commercial, mix uses (residential cum commercial) and residential-religion has a significant relationship with rental values while commercial-residential, residential-industrial and residential-recreational has no significant relationship with rental values in the study area, which implied that residential-commercial; mix uses (residential cum commercial) and residential-religion land-use succession had a higher effect on rental values. The implication may due to change from a lower profitable use to higher profitable use as demonstrated in the benefits derivable from subjecting the property to its highest and best use as supported by (Famarinde, 2007); and Burges, Sector and Hoyts' theory as cited in (Mc Donagh, 2015). Hence, the information provided on land- 
use succession and property value in this study is expected to enhance property investment decision.

To enhance property investment decision, there is a need for collective efforts on the part of Town Planning and Land Services Department, Estate Surveyors and Valuers as well as and Building Occupiers in the study area. The study recommends that land-use succession in the study area should be regulated, monitored and controlled by the various relevant government agencies of the City. Also, policies on land use should have commercial and residential area demarcated to avoid indiscriminate land-use succession as a result of increased urbanisation in the city. It is important to ensure that the law guiding land use is enforced on individual landowners and investors/developers in the study area, to avoid irregular and uncontrolled land-use succession in the study area and to reduce the change in the use of land from residential to commercial. Also, individual landowners, investors and developers should avoid the arbitrary increase in rental value, so that both the privileged and the less privileged people will benefit.

\section{REFERENCES}

1. Ajibola, M. O., Awodiran, O. O., and Salu-Kosoko O. (2013). Effects of Infrastructure on Property Values in Unity Estate, Lagos, Nigeria: International Journal of Economy, Management and Social Sciences: 2(5): 195-201.

2. Briassoulis, H. (2015). Analysis of Land Use Change: Theoretical and Modelling Approaches http://www.rri.wvu.edu/WebBook/Briassoulis/contents.htm

3. Cellmer, R., Senetra, A., Szczepanska, A. (2012). The Effect of Environmental Factors on Real Estate Value FIG Working Week 2012 Knowing to Manage the Territory, Protect the Environment, Evaluate the Cultural Heritage.

4. Cloete, E. C. and Chikafalimani, S. H. P. (2001). Overview of the Property Industry in Malawi: Joint 3rd AfRES/TIVEA/RICS Foundation Conference on Real Estate in Africa held in Arusha, Tanzania: 23 - 25.

5. Farinmade, A. (2007). Land Use Conversion in Surulere Local Government, Lagos, Nigeria Department of Urban and Regional Planning University of Lagos, AkokaYaba, Lagos.

6. Harvey, J. (1996). Urban Land Economics, Fourth Edition, Macmillan Press.

7. Hassan, O.A. (2015). Land Use Succession and Real Estate Transactions in Ilorin Metropolis. Unpublished M.sc Thesis submitted to the Department of Estate Management Faculty of Environmental Design and Management Obafemi Awolowo University Ile-Ife Osun State, Nigeria.

8. Johnson, T.; Davis, K.; and Shapiro, E. (2005). Modern Methods of Valuation of Land, Houses and Buildings: Estate Gazette (London) and EPP Books Services (Ghana).

9. Kabanze, B. M. (2003). The Impact of the Expansion of Lusaka's Central Business District (Cbd) on the Residential Zones: Case Study of Fairview.

10. Kieran T. (2004). Grow Rich with the Property Cycle. Retrieved from "https://en.wikipedia.org/w/index.php?title=Property_cycle\&oldid=670048143.

11. Makinde, O.O, (2019). Neighbourhood Quality in Gated Communities in Ibadan, Oyo State, Nigeria. Unpublished PhD. (Arch) Thesis Obafemi Awolowo University, Ile Ife.

12. Meyer, W.B. and Turner, B.L. II, (1996). "Land-Use/Land-Cover Change: Challenges for Geographers." Geojournal 39(3): 237-240. 
13. Nigerian Institution of Estate Surveyors and Valuers, (NIESV) (1985). Guidance Notes on Property Valuation, The Nigerian Institution of Estate Surveyors and Valuers, Lagos. (1st Edition)

14. Nwanekezie, O. F., Iroegbu A. N., Alozie M. and Okorocha K. A. (2010). Issues in Land Use Allocation in Nigeria: Nigerian Journal of Research and Production: 17(2).

15. Oduwaye, L. (2013). Urban Planning Implications of Changing Land Use Structure of Metropolitan Lagos, Nigeria: reviewed paper; Proceedings REAL CORP 2013 Tagungsband Rome, Italy. 20-23.

16. Ogungbemi, O. A. (2012). Factors Influencing Change of Use and Its Attendant Problems: Case Study of Yaya Abatan Ogba, Lagos State: Journal of Emerging Trends in Economics and Management Sciences (JETEMS) 3(6): 901-906.

17. Olaore, G.O. (1998). Values of Land and Rentage of Shelter in Nigeria Urban Areas: A Case Study of Kaduna. Niser Monograph Series, Ibadan.

18. Olayiwola, L. M., O.A. Adeleye, and A.O. Oduwaye (2006). Spatial Variation in Residential Land Value Determinants in Lagos Nigeria: Paper presented at the International Conference on Promoting Land Administration and Good Governance. 5th FIG Regional Conference, Accra, Ghana.

19. Oni, A. O. (2008a). An Empirical Study of the Lagos State Rent Edict of 1997. Journal of the Nigerian Institution of Estate Surveyors and Valuers. ISSN 1597-653X. 31 (1) $20-32$.

20. Oni, A. O. (2008b). Arterial Road Network and Commercial Property Values in Ikeja, Nigeria: unpublished PhD. A thesis submitted to the Department of Estate Management, Covenant University, Ota, Ogun State, Nigeria.

21. Oyebanji, A. O. (2003). Principles of Land Use Economics Centre for Environmental Planning, Development and Management Lagos.

22. Reed, S.and Crawford, M. (2014). Prices and Spending"Image" How does Consumer Spending Change During Boom, Recession, and Recovery? 3 (15).

23. Tse, R. Y. C. and Love, P. E. D. (2000). Measuring Residential Property Values in Hong Kong Property Management.18 (5): 366 - 374.

24. Turner, B.L. II Skole, D. Sanderson, S. Fischer, G. Fresco, L. and Leemans, R. (1995). Land-Use and Land-Cover Change; Science/Research Plan: IGBP Report HDP Report IGBP, HDP, Stockholm and Geneva, 35 (7). 